\title{
Insectivores (Soricomorpha, Mammalia) from the Pliocene and Pleistocene of Transbaikalia and Irkutsk region (Russia)
}

\author{
Barbara Rzebik-Kowalska \\ Institute of Systematics and Evolution of Animals, Polish Academy of Sciences, Stawkowska 17, 31-016 Kraków, Poland
}

Available online 31 August 2007

\begin{abstract}
Remains of Talpidae and Soricidae have been found in Pliocene and Pleistocene sediments of 10 localities in Western Transbaikalia and the Irkutsk Region. They belong to five genera and 15 species. Besides fossil (Petenyia sp., Sorex palaeosibiriensis) and Recent taxa (Asioscalops altaica, Crocidura sp., Neomys fodiens, Sorex minutissimus, Sorex minutus, Sorex roboratus, Sorex cf. isodon and Sorex cf. daphaenodon) known from Asia, descriptions of two Sorex species from the Baikal region (Sorex erbajevae and Sorex baikalensis) are given. Thus, the number of fossil Sorex species cited to date from Asia has increased to 21 .
\end{abstract}

(C) 2007 Elsevier Ltd and INQUA. All rights reserved.

\section{Introduction}

Central and East Asia are regarded as the cradle of various taxa, including those that appeared in Europe as immigrants in the course of the Pliocene and Pleistocene. However, the current knowledge of fossil insectivore mammals from Asia is very limited. In general, the diversity of fossils depends mainly on the intensity of palaeontological research, which is greater in Europe and in North America than in Asia. Although shrews are a major element in most late Cenozoic micromammal assemblages, studies of this group are usually of secondary importance in comparison with those on rodents. So there is only vague taxonomic information about fossil soricids and insectivore mammals in general.

The Recent fauna of shrews of the genus Sorex include 74 species (Lapini and Testone, 1998; Wolsan and Hutterer, 1998; Brünner et al., 2002). They populate almost the entire Holarctic with the exception of North Africa: 38 species inhabit North America (37 endemic and one common with Asia); 31 species inhabit Asia (24 endemic, six common with Europe and one common with North America); and only 12 species are known in Europe (six endemic and six common with Asia). In the past shrews were widely distributed in Eurasia and in North America. However, from the vast Asian continent

E-mail address: rzebik@isez.pan.krakow.pl only 16 extinct forms have been described, in contrast to 34 fossil Sorex species from North America and 28 from Europe (Harris, 1998; Rzebik-Kowalska, 1998, 2005; Storch et al., 1998; Zaitsev and Baryshnikov, 2002). Taking into consideration the different geological history and different past climatic conditions in Europe and Asia, it is safe to assume that Asia must have been inhabited by many more forms than are known at present. In this connection, new information about fossil insectivore mammal fauna from Asia is very valuable and important.

\section{Material}

The material received from Dr. Margarita Erbajeva comes from 10 localities of Transbaikalia [Zasukhino II, Tologoi I.1, Tologoi II.2, Tologoi 3 (upper layer)] and of the Irkutsk Region (Rykovo, Razdolinskaya 7 Cave, Kozlovka Cave, Bolshaya Baidinskaya Cave, Kurtun I Cave and Malta site). Tologoi I.1 is dated to the early Late Pliocene (MN16b), and Zasukhino II and Tologoi II.2 to the Early Pleistocene. The other localities are of Late Pleistocene. Detailed description, measurements and photographs of the materials from these sites, especially of new fossil Sorex species, is given in a separate paper (Rzebik-Kowalska, 2007). Sorex gracilimus Thomas, 1907 and Sorex praecaecutiens Mezhzherin, 1972 identified previously have not been found among the studied material. The recognition and description of the latter form has never been published. 


\section{Systematics}

Superorder Insectivora (sensu Novacek, 1986)

Order Lipotyphla Haeckel, 1866

Suborder Soricomorpha Saban, 1954

Family Talpidae Fischer von Waldheim, 1817

Genus Asioscalops Stroganov, 1941

Asioscalops altaica Nikolsky, 1883

The size and morphology of one mole mandible from Razdolinskaya 7 Cave lies in the range of variation of A. altaica Nikolsky, 1883, the only Recent mole living in Central Siberia. Three other Recent moles, the European Talpa europaea Linnaeus, 1758 and the Siberian Mogera vogura Temminck, 1842 and Mogera robusta Nehring, 1891 have larger teeth, and they do not reach Baikalia at present. The eastern range boundary of $T$. europaea is in the vicinity of the Irtish River and two species of Mogera have ranges further eastwards (East China, Primorie, Japan, Korea, etc.).

\section{Talpidae gen. et sp. indet.}

The second mole mandible from Razdolinskaya 7 Cave is larger than the one mentioned above. It is badly preserved and cannot be identified to the genus level.

Shrews (Soricidae) represent two subfamilies: the Crocidurinae and Soricinae.

Family Soricidae Fischer von Waldheim 1817

Subfamily Crocidurinae Milne-Edwards, 1868-1874

Genus Crocidura Wagler, 1832

Crocidura sp.

One mandible of Crocidura Wagler, 1832 was found in the Tologoi II.2 locality. The small size of this mandible is close to that of the Recent Crocidura suaveolens (Pallas, 1811) which occupies a vast territory from Spain to Korea and is present in North Africa, but it is not known in the high latitudes of Eurasia. Two other Siberian species of Crocidura, Crocidura lasiura Dobson, 1980 and Crocidura sibirica Dukelsky 1930 are much larger than the extinct form from Transbaikalia. As the material is very scarce and badly preserved, the mandible from Tologoi II.2 is identified as Crocidura sp.

Unfortunately, knowledge of the fossil Crocidura in Asia is very limited. So far, only three specifically named species are known: Crocidura wongi Pei, 1936, and Crocidura horsfieldi (Tomes, 1856) from China and Crocidura dzinezu$m i$ (Temminck, 1842) from Japan; all three species are of Pleistocene age. From Asia, only Crocidurinae gen. et sp. indet. or Crocidura sp. was listed by Storch et al. (1998).

Subfamily Soricinae Fischer von Waldheim, 1817

Tribe Blarinellini Reumer, 1998

Genus Petenyia Kormos, 1934

Petenyia sp.
Four fragments of mandibles found in Tologoi I.1, dated to the early Late Pliocene (MN16b) have been identified as belonging to the fossil genus Petenyia Kormos, 1934. Three species are currently accepted, two taxa from Europe (Petenyia hungarica Kormos, 1934, Petenyia dubia Bachmayer and Wilson, 1970) and one (Petenyia katrinae Qiu and Storch, 2000) from Asia. In Asia, besides P. katrinae, Petenyia sp. was cited from several localities of West Siberia, Mongolia and Transbaikalia. The Asiatic species $P$. katrinae can be distinguished from the European species by the morphology of the upper teeth. Unfortunately, in Tologoi I.1 the upper jaws are not found. Without more and better preserved material, the specific position of Petenyia from Tologoi I.1 cannot be fixed (cf. RzebikKowalska, 1998; Qiu and Storch, 2000).

Tribe Neomyini Matschie, 1909

Genus Neomys Kaup, 1829

Neomys fodiens (Pennant, 1771)

The morphology of two mandible fragments from Kozlovka Cave allowed the identification of these remains as Neomys Kaup, 1829, and their large size indicates $N$. fodiens (Pennent, 1771). The other four fossil species of Neomys: Neomys newtoni Hinton, 1911, Neomys browni Hinton, 1911, Neomys hintoni Zaitsev and Baryshnikov (2002), and Neomys intermedius Brunner, 1952, and two Recent Neomys anomalus Cabrera, 1907, and Neomys teres Miller, 1908 (= Neomys schelkovnikovi Satunin, 1913) are much smaller than the Siberian form. As well, at present they are not present in the vicinity of Lake Baikal (Rzebik-Kowalska, 1998; Zaitsev and Baryshnikov, 2002).

$N$. fodiens is the only species of this genus recently living in the Baikal area. It occupies a large range within the Northern and Middle (Central) Palaearctic. Fossil remains of $N$. fodiens are known in Europe from the Middle Pleistocene. This discovery in Asia is the first record of fossil $N$. fodiens in this continent.

Tribe Soricini Fischer von Waldheim, 1817

Genus Sorex Linnaeus, 1758

Among materials from Siberia, nine taxa of the genus Sorex have been recorded.

Sorex minutissimus Zimmermann, 1780

One mandible of $S$. minutissimus Zimmermann, 1780 was found in Bolshaya Baidinskaya Cave. Today, the area of distribution of the smallest Recent Sorex extends from Finland to East Siberia and Japan. In the past extinct forms of this species were known mainly from Europe. In the Pleistocene the range of $S$. minutissimus spread westwards (Poland, Germany, France, England) and southwards (Slovakia, Austria, Bulgaria) (Rzebik-Kowalska, 1998). In Asia, fossil S. minutissimus was listed by Storch et al. (1998), from the Middle Pleistocene of Honshu Island in Japan. 
Sorex minutus Linnaeus, 1766

Fossil remains of $S$. minutus Linnaeus, 1766 were found in two localities (Caves Kozlovka and Razdolinskaya 7). Today, it occupies a large area from North Spain to the western bank of Lake Baikal. In Europe it is known since the Early Pliocene (dating back about five million years). Therefore, it was the first of the living Sorex species that appeared in the European continent and persisted there until Recent time (Rzebik-Kowalska, 2005). In Asia, fossil $S$. minutus are scarce. It was found in the Early Pleistocene deposits of China (Storch et al., 1998).

The origin and phylogenetic relationship of $S$. minutus with other fossil and Recent Sorex is not clear. According to Storch (1995), the probable ancestor of S. minutus could be $S$. minutoides, described from the Late Miocene locality Ertemte 2 in China.

\section{Sorex roboratus Hollister, 1913}

One well-preserved mandible from Bolshaya Baidinskaya Cave does not differ from mandibles of the Recent east Palaearctic shrew, S. roboratus Hollister, 1913. According to Yudin (1989) it currently inhabits a large territory, from the eastern bank of the $\mathrm{Ob}$ River to Chukotka and Primorie. This is the first fossil record of S. roboratus.

Sorex cf. isodon Turov, 1924 and Sorex cf. daphaenodon Thomas, 1907

Two other species, Sorex cf. isodon Turov, 1924 and Sorex cf. daphaenodon Thomas, 1907, known from Bolshaya Baidinskaya and Kozlovka caves respectively, are similar in size and morphological features to the Recent taxa S. isodon Turov, 1924 and S. daphaenodon Thomas, 1907.

The currant area of distribution of $S$. isodon is a large territory of northeastern Eurasia, from Scandinavia to Kamchatka, the Kuril Islands, Sakhalin, and Primorie. However, the southern boundary of its range is not clear. $S$. daphaenodon also inhabits a large area of the eastern Palaearctic, including Transbaikalia and Pribaikalie. These two species are identified for the first time in the fossil record from Asia.

Three other Sorex species discovered in south Siberia are extinct forms:

\section{Sorex palaeosibiriensis Mezhzherin, 1972}

Sorex palaeosibiriensis is found in Cave Razdolinskaya 7, located in Prebaikalia. It was known only from its type locality in Western Transbaikalia (Mezhzherin, 1972).

Mezhzherin (1972) presented satisfactory descriptions, a photograph of the mandible, and measurements of $S$. palaeosibiriensis as well as the description of another species, $S$. praecaecutiens. He stated that these species were described for the first time by Mezhzherin and Pokatilov in a 1969 paper from the Early Pleistocene locality situated in the vicinity of Ulan Ude, Transbaikalia. However, no paper was published by Mezhzherin and Pokatilov in 1969. In this situation, according to the ICZN, the exact date of these two species descriptions is the year 1972, and the name of the author is Mezhzherin.

\section{Sorex erbajevae Rzebik-Kowalska, 2007}

The remains of $S$. erbajevae were found in six localities: Rykovo II, Bolshaya Baidinskaya Cave, Kozlovka Cave, Kurtun I, Tologoi 3 (upper layer) and Malta. The moderate size of specimens suggests that they could belong to the Recent Sorex caecutiens Laxmann, 1788 or Sorex tundrensis Merriam, 1900; as well they are similar in size to S. palaeosibiriensis. Other living or fossil Siberian Sorex are smaller or larger and their teeth morphology is quite different. S. erbajevae resembles in its morphology the fossil S. praecaecutiens described by Mezhzherin (1972) from the vicinity of Ulan Ude. However, S. praecaecutiens is much larger than S. erbajevae.

\section{Sorex baikalensis Rzebik-Kowalska, 2007}

This species is known from Razdolinskaya 7 Cave. $S$. baikalensis is characterized by its large size and somewhat bulbous teeth, resembling those of European species of subgenus Sorex (Drepanosorex) Kretzoi, 1941 (Reumer, 1985). The size of shrews from Razdolinskaya 7 Cave is also more or less similar to that of several Sorex species (e. g. Sorex unguiculatus Dobson, 1890, $S$. araneus Linnaeus, 1758, S. isodon, $S$. daphaenodon, and $S$. roboratus) existing today in Siberia. In its teeth morphology, S. baikalensis differs from all Recent and fossil Sorex species of similar size known at present.

\section{Conclusion}

The fossils from 10 localities of the Baikalian region contain 96 remains of insectivore mammals. They are represented mostly by mandible fragments and belong to two families (Talpidae and Soricidae), five genera (Asioscalops, Crocidura, Petenyia, Neomys, and Sorex), 15 species and 49 individuals. Tables 1 and 2 show the species compositions in the localities. Six species of shrews

Table 1

Shrews from the early Late Pliocene-Early Pleistocene localities

\begin{tabular}{llll}
\hline & Zasukhino II & Tologoi I.1 & Tologoi II.2 \\
\hline Soricidae & & & \\
$\quad$ Crocidura sp. & - & - & + \\
Petenyia sp. & - & + & - \\
Sorex & & & \\
$\quad$ Sorex sp. (medium size) & + & - & - \\
\hline
\end{tabular}


Table 2

Shrews from the Late Pleistocene localities of the Baikalian region

\begin{tabular}{|c|c|c|c|c|c|c|c|}
\hline & $\begin{array}{l}\text { Razdolinskaya } \\
7\end{array}$ & Kozlovka & B. Baidinskaya & $\begin{array}{l}\text { Kurtun I } \\
\text { (upper 1.) }\end{array}$ & Tologoi 3 & Malta & Rykovo II \\
\hline \multicolumn{8}{|l|}{ Talpidae } \\
\hline \multicolumn{8}{|l|}{ Asioscalops } \\
\hline A. altaica Nikolsky, 1883 & + & - & - & - & - & - & - \\
\hline Talpidae gen. et sp. indet. & + & - & - & - & - & - & - \\
\hline \multicolumn{8}{|l|}{ Soricidae } \\
\hline \multicolumn{8}{|l|}{ Neomys } \\
\hline N. fodiens (Pennant, 1771) & - & + & - & - & - & - & - \\
\hline \multicolumn{8}{|l|}{ Sorex } \\
\hline S. minutissimus & - & - & + & - & - & - & - \\
\hline \multicolumn{8}{|l|}{ Zimmermann, 1780} \\
\hline S. minutus Linnaeus, 1766 & + & + & - & - & - & - & - \\
\hline S. palaeosibiriensis & + & - & - & - & - & - & - \\
\hline \multicolumn{8}{|l|}{ Mezhzherin, 1972} \\
\hline $\begin{array}{l}\text { S. erbajevae Rzebik- } \\
\text { Kowalska, } 2007\end{array}$ & - & + & + & + & + & + & + \\
\hline S. roboratus Hollister, 1913 & - & - & + & - & - & - & - \\
\hline S. cf. isodon Turov, 1924 & - & - & + & - & - & - & - \\
\hline $\begin{array}{l}\text { S. cf. daphaenodon Thomas, } \\
1907\end{array}$ & - & + & - & - & - & - & - \\
\hline $\begin{array}{l}\text { S. baikalensis Rzebik- } \\
\text { Kowalska, } 2007\end{array}$ & + & - & - & - & - & - & - \\
\hline
\end{tabular}

( $N$. fodiens, $S$. minutissimus, $S$. minutus, $S$. roboratus, $S$. cf. isodon, and $S$. cf. daphaenodon) and one mole (A. altaica) are Recent species of Siberian fauna, and four other shrews (Petenyia sp., S. palaeosibiriensis, S. erbajevae, and $S$. bajkalensis ) are extinct species. The generic and specific status of the mole (Talpidae gen. et sp. indet.) and of two shrews (Crocidura sp., and Sorex sp.) is uncertain, as are their relationships in living or extinct forms.

The insectivore remains were distributed irregularly in the localities. The most abundant specimens, belonging to five species (two moles and three shrews), were found in Razdolinskaya 7 Cave. Bolshaya Baidinskaya and Kozlovka Caves yielded remains of four species (all shrews), and in the other localities remains of only one species of shrew have been found. Among insectivores the most numerous species were shrews of the genus Sorex. Others (moles and shrews of the genera Crocidura, Petenyia and Neomys) were very scarce (usually one taxon was present).

The predominant forms in the paleontological materials were middle-sized shrews. When more than one Sorex species was present, they belonged to different size categories: small, middle and large. The Kozlovka Cave fauna included small-sized $S$. minutus, middle-sized $S$. erbajevae and large $S$. cf. dapahaenodon; in Razdolinskaya 7 Cave there were small-sized $S$. minutus, middle-sized S. palaeosibiriensis and large-sized S. baikalensis. Similar size distribution exists in the recent faunas, and competition was avoided by adaptation to different ecological niches in the past as well.

For the first time, fossils of four Recent species of shrews, $N$. fodiens, $S$. roboratus, $S$. cf. isodon and $S$. cf. daphaenodon, and two new extinct Sorex species (S. erbajevae and $S$. baikalensis) are recorded from Asia. This has increased the number of extinct species of the genus Sorex, known in Asia, from 16 to 21.

\section{References}

Brünner, H., Lugon-Moulin, N., Balloux, F., Fumagalli, L., Hauser, J., 2002. A taxonomical reevaluation of the Valais chromosome race of the common shrew Sorex araneus (Insectivora: Soricidae). Acta Theriologica 47, 245-275.

Harris, A.H., 1998. Fossil history of shrews in North America. In: Wójcik, J.M., Wolsan, M. (Eds.), Evolution of Shrews. Mammal Research Institute, Polish Academy of Sciences, Białowieża, pp. 133-149.

Lapini, L., Testone, R., 1998. A new Sorex from north-eastern Italy (Mammalia, Insectivora, Soricidae). Gortania-Atti del Museo Friulano de Storia Naturale (Udine, Italy) 20, 231-250.

Mezhzherin, V.A., 1972. Shrews (Sorex, Insectivora, Mammalia) from Pleistocene Deposits of the USRR. Publishing House "Nauka," Siberian Branch, Novosibirsk, pp. 17-130.

Qiu, Z.D., Storch, G., 2000. The early Pliocene micromammalian fauna of Bilike, inner Mongolia, China (Mammalia: Lipotyphla, Chiroptera, Rodentia, Lagomorpha). Senckenbergiana Lethaea 80 (1), 137-229.

Reumer, J.W.F., 1985. The generic status and species of Drepanosorex reconsidered (Mammalia, Soricidae). Revue de Paléobiologie 4 (1), $53-58$.

Rzebik-Kowalska, B., 1998. Fossil history of shrews in Europe. In: Wójcik, J.M., Wolsan, M. (Eds.), Evolution of Shrews. Mammal Research Institute, Polish Academy of Sciences, Białowieża pp. 23-92.

Rzebik-Kowalska, B., 2005. Paleontological relationships of European Sorex. In: Merritt, J.F., Churchfield, S., Hutterer, R., Sheftel, B.I. (Eds.), Advances in the Biology of Shrews II. Special Publication of the International Society of Shrew Biologists, New York pp. 1-8.

Rzebik-Kowalska, B., 2007. New data on Soricomorpha (Lipotyphla, Mammalia) from the Pliocene and Pleistocene of Transbaikalia and 
Irkutsk Region (Russia). Acta Zoologica Cracoviensia 50A (1-2), 15-48.

Storch, G., 1995. The Neogene mammalian faunas of Ertemte and Harr Obo in Inner Mongolia (Nei Mongol), China. 11. Soricidae (Insectivora). Senckenbergiana Lethaea 75, 221-251.

Storch, G., Qiu, Zh., Zazhigin, V.S., 1998. Fossil history of shrews in Asia. In: Wójcik, J.M., Wolsan, M. (Eds.), Evolution of Shrews. Mammal Research Institute, Polish Academy of Sciences, Białowieża, pp. 92-117.
Wolsan, M., Hutterer, R., 1998. A list of the living species of shrews. In: Wójcik, J.M., Wolsan, M. (Eds.), Evolution of Shrews. Mammal Research Institute, Polish Academy of Sciences, Białowieża, pp. 425-458.

Yudin, B.S., 1989. Insectivore Mammals of Siberia. Publishing House "Nauka," Siberian Branch, Novosibirsk, p. 60.

Zaitsev, M.V., Baryshnikov, G.F., 2002. Pleistocene Soricidae (Lipotyphla, Insectivora, Mammalia) from Treugolnaya Cave, Northern Caucasus, Russia. Acta Zoologica Cracoviensia 45 (2), 283-305. 